\title{
Promoting Reflexive Thinking and Adaptive Expertise Through Video Capturing to Challenge Postgraduate Primary Student Teachers to Think, Know, Feel, and Act Like a Teacher
}

\author{
Steven S Sexton*, Sandra Williamson-Leadley \\ College of Education, University of Otago, New Zealand \\ *Corresponding Author: steven.sexton@otago.ac.nz
}

\section{ABSTRACT}

This article reports on a study of how a 1-year, course-taught, master's level initial teacher education (ITE) program challenged primary student teachers $(n=4)$ in developing their sense of self-as-teacher. This study examined how the program's incorporation of video capturing technology impacted on these student teachers' development of reflexivity and adaptive expertise. Student teachers self-selected a community of practice to include two experienced teachers acting as facilitators. Using a secure video capturing system, student teachers collected samples of teaching practice. Then, through student teacher led discussions, they and their community of practice examined how they were developing as teachers. Results indicate how video capturing provided the experiences necessary for these student teachers to reflect on teaching practice and learn how to think, know, feel, and act like a teacher. Implications of this research highlight the benefits of student teachers actually seeing their own teaching practice, and then, using these examples of teaching as evidence of how they were becoming reflexive and adaptive teachers.

KEY WORDS: postgraduate education; student teaching; primary teacher education; technology in education

\section{INTRODUCTION}

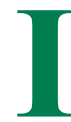

n 2005, Ruth Kane in her final report on Initial Teacher Education (ITE) policy and practice in New Zealand, highlighted how ITE was, "a complex and multi-faceted endeavor" (p. xii). Kane noted that there were 27 different institutions offering 85 ITE qualifications through 131 programs applying a range of delivery modes to include faceto-face, distance, flexible, web-based, and field-based. ITE in New Zealand is now at a crossroads. For the past two decades, those seeking to gain ITE qualifications in primary education completed either a 3-year undergraduate degree program or a 1-year graduate diploma. In 2013, the Ministry of Education invited tertiary providers to develop exemplary 1-year, coursetaught, master's level ITE programs. These new exemplary Master of Teaching and Learning (MTchgLn) programs began in 2014 (Parata, 2014).

The Ministry of Education (2016) noted that the purpose of these new exemplary ITE qualifications was to lift the quality of graduating teachers' practice. To do this, programs needed two key interventions, "the specification of graduate outcomes and the quality of the practicum experience and induction into the profession" (para. 11). As these exemplary programs were new to New Zealand, the Ministry of Education acknowledged that an objective of this initiative was to determine what exemplary practice in New Zealand looked like. The programs selected in 2013 to begin 3-year pilots demonstrated three elements. First, a clear articulation of the outcomes that it is graduating teachers would be able to demonstrate and how these differed from the provider's existing programs. Second, an approach to practicum that was significantly different to existing programs that integrated both provider and the school through a collaborated approach. Finally, how the provider would support the capability building of personnel in the program to support high-quality teacher education for student teachers, mentor teachers, and teacher educators. These three elements derive from an established body of New Zealand research (Cameron and Baker, 2004; Kane, 2005) and international research on exemplary programs (Lind, 2013).

Kane's (2005) report on ITE specifically noted the importance of a program's conceptual framework in determining whether it is coherent and effective for teacher education. Cameron and Baker's (2004) review of research noted the pervasiveness and tenacity of student teachers' beliefs about teaching and teachers. Specifically, the review highlighted how these needed to be explored so as not to limit student teachers' ability to acquire new knowledge and understanding. In 2013, Lind reported the five overarching characteristics of exemplary programs in countries similar to New Zealand. First, these programs have highly selective entry. Second, programs have extensive and sustained student teaching practice throughout their ITE program. Third, programs are grounded in meaningful partnerships between provider and schools. Fourth, programs ensure student teachers develop abilities to 
assess their own students' learning needs and then implement approaches necessary to address these needs. Finally, programs support student teachers into suitable teaching positions for their $1^{\text {st }}$ years of teaching.

Importantly for this article, Feiman-Nemser (2008) argued that teachers' learning to teach required, "learning to think like a teacher, learning to know like a teacher, learning to feel like a teacher, and learning to act like a teacher" (p. 214, italics in original). This paper's study explicitly sought to investigate how an exemplary MTchgLn program's use of video capturing impacted on student teachers' learning from their extensive and sustained classroom experience. The program's conceptual framework supported and facilitated student teachers through realistic teacher education (Korthagen et al., 2008), adaptive expertise (Timperley, 2013), and critical reflexivity (Cunliffe, 2004; Thompson and Pascal, 2012) to challenge these student teachers' beliefs about teaching and being the teacher. Specifically, this program intended to make explicitly visible both the teaching and learning of teachers in classrooms (Hattie, 2009).

\section{Video Capture Self-study/Community of Practice Group Sessions}

Across a number of New Zealand and international studies, both ITE providers and student teachers have identified the professional teaching experience as one of the more challenging, positive, and significant aspects of the preservice teacher education (Conner et al., 2008; GroundwaterSmith et al., 2006; Haigh, 2013; Hoban, 2005; Simpson and Grudnoff, 2013). The importance of the coherence and integration between ITE course work and professional experience has been highlighted as an essential component of exemplary teacher education programs (Lind, 2013).

Video capturing is an innovative approach aimed at meeting the challenge of student teachers developing as reflexive practitioners. This study's MTchgLn program's conceptual framework defines reflexivity as the process of critical self-inspection on one's biases, assumptions, theoretical predispositions, and preferences. Explicitly positioning the student teacher as part of the setting, context, and social phenomenon, he or she is working in and therefore has a part to play in contributing to that setting, context, and phenomena. Specifically, student teachers captured video footage of their classroom teaching practice for both self and collaborative appraisal. The shared use of personal video promotes working within a community of practice, learning from one another, and engaging in a manner designed to foster learning conversations, bringing meaningful linking of theory, and practice (Le Cornu, 2010; Youens et al., 2014). Video capturing allows student teachers to see, hear, and review what actually happened and not what was "remembered." Although concerned with beginning teachers, Hatch and Grossman (2009) noted how videos of teaching practice facilitated opportunities to both see and engage in collaborative inquiry about "real context" teaching practice. Specifically, this study's video capturing technology supported student teachers' collaborative inquiry through narrative threads. The narrative threads of commentary available through the video capturing software promoted the connection of ideas within class, within tutorials, and within schools improving their understanding of the network of relationships that exist within and across learning communities, and to appreciate the support these relationships can offer to focus on individual student learning needs.

Video capturing of teaching practice is an approach that encourages students to develop as agents of change by exposing them to the theoretical tools and practical experiences needed to critique and build on what they experienced (Ballard, 2012). It was envisaged that over the course of their program this method would be a transformative. Specifically, it was hoped the student teachers would move from reflection on action to reflexive thought about how their actions, assumptions, and beliefs inform their teaching practice.

Through their practice, student teachers were encouraged to engage in critical thinking about the coherence between their pedagogical practice and the theoretical underpinnings by questioning dominant discourses, challenge hegemonic beliefs, and clarify their own thinking about what is important in effective teaching. Out of these reflections, students were challenged to make sense of their experiences, construct their own beliefs about effective pedagogy, and then, as necessary, adapt their practices to ensure their continuing professional growth. However, while student teachers are apt at reflecting on their experience (descriptive voice), they struggle to engage reflexively, that is, to clarify the ways in which their work is underpinned by theory (Haigh, 2013; Schön, 1987; Thompson and Pascal, 2012). This project facilitated student teachers' ability to integrate their professional and personal learning as well as beginning to theorize about their own professional self: critically examining the beliefs, experiences and theoretical understandings that shape the way they work with learners. An anticipated outcome of this project was to strengthen the student teachers' ability to demonstrate reflexive thinking about their adaptive practice as teachers.

The annotation of video as a method of learning is relatively new in education and a search for studies employing video metadata as part of teacher education gave limited results. Video of practice is not new for professional development; however, the only published research concerning New Zealand involved the videoing of teachers for peer review and not the student teachers' own teaching practice (Charteris and Smardon, 2013). As such, this appears to be a new approach in New Zealand ITE. International research has shown that student teachers value and benefit from ready access to feedback from and discussion with a peer (Le Cornu, 2010; Nokes et al., 2008; Seraphin et al., 2012). The use of video, collaborative video markup and video-related narratives being explored in this project situates the students' learning experiences within a social process. Student teachers were encouraged to develop and exercise the skills of adaptive help 
seeking, that is, to identify and strategically seek help address their concerns and questions as opportunities to learn (Steed and Poskitt, 2010). This orientation to seeking help is a move from the concept of practice to a fully realized inquiry-based approach. Guiding and assessing the professional experiences will be based on a close partnership among student teachers, University Faculty, and school Mentor Teachers (community of practice/inquiry) so that students become proactive practitioners of feedback/feedforward information as part of an overall drive to understand and enhance their teaching as inquiry (Feldman et al., 2012; Ministry of Education, 2007).

As an exemplary program, these student teachers met highly selective entry requirements. As a result, it was anticipated that the students entering this program would have had a history of academic success and a favorable self-efficacy in their abilities. This study's MTchgLn program was designed to develop an understanding of the affordances of working as a community of practice/inquiry and the recognition of the role of social context in learning (Lave and Wenger, 1991) is integral to this project. The Best Evidence Synthesis on Professional Learning (Timperley et al., 2007) emphasized the place of social interaction among teachers as peers and those who bring relevant expertise. As such, graduating student teachers are positioned to challenge group norms, seek feedback, and seek clarification to support deep constructs of practice (Timperley, 2013). The challenge is how to guide these student teachers to enable them to reconsider and reconstruct their own everyday theories and to integrate their practice with more formal theories (Timperley, 2013).

\section{The study}

This paper reports on four $(n=4)$ of the 2016 exemplary MTchgLn program primary student teachers. Specifically, this study investigated the following research question:

How did the use of video capturing in this 1-year, course taught, master's level program in ITE influence how these student teachers developed their sense of self-as-teacher as they learned to think, know, feel, and act like a teacher?

\section{METHODS}

\section{Participants}

The four participants were student teachers in the MTchgLn program in Primary Education at a large university in New Zealand. These student teachers ranged in age from 22 to 24 with a median age of 22.5. There were three females and one male. Two self-reported their ethnicity as New Zealand European, one as other European, and one as New Zealand European, and Asian. These four student teachers were selected as their placement school was supportive and encouraged these students teachers to start taking advantage of this opportunity early in their placement. To determine the impact of this program on how these student teachers saw themselves developing in learning how to think, know, feel, and act like a teacher focus group sessions were used in this study.

\section{Project Plan}

The project was integrated into the 2016 MTchgLn program. The program started on January $5^{\text {th }} 2016$ with a 4-week block course to introduce the student teachers to teaching in the New Zealand context. As part of this, the lead author explained the project to the student teachers and how this program was designed to facilitate their development in becoming what the program's conceptual framework defines as reflexive (Ministry of Education, 2016; Lind, 2013). The student teachers were introduced to Cunliffe's (2004) and Thompson and Pascal's (2012) concepts of reflection as well as Timperley's (2013) adaptive expertise on how this program positions critical reflexivity to support their own adaptive practice for reflection for action. The project plan is outlined in Table 1.

This paper reports on how these four primary student teachers used the video capturing system to develop their sense of self as the teacher over the course of this program (Figure 1).

\section{INITIAL RESULTS}

To identify how the use of video capturing was impacting on these student teachers, focus group sessions were held. All four student teachers were in the same partner school and worked in pairs to review video samples. The student teachers aimed to meet once a week to peer review the video footage of their teaching.

In the first focus group meeting in March, the student teachers reported that having a dedicated time to meet meant that the reviewing of their video was more likely to be completed. Lucy (all names are pseudonyms) identified that the first hurdle they encountered was the logistics of the student teachers being able to be in each other's classroom to video the lesson, "An issue with the video was trying to find a time to video each other, so we needed to schedule that in". The student teachers initially felt it was important to video each other. They argued that seeing the session in context made it easier to give feedback to the other person.

For these student teachers, it was the first time they had ever seen themselves literally in the role of a teacher. Amber's comment was representative of the group, "[it was] interesting watching each other as we are at the same level of teaching as opposed to watching our Mentor Teacher, who is an experienced teacher. It's a more of a level playing field". When asked to explain what was interesting, their comments centered on what they looked and sounded like and how this affected the children they were teaching:

Having a child give an answer and then repeating the answer. The children almost switch off because they know that I will repeat the answer so they do not need to listen to that child. Active listening [by the children] is not so hot (Lucy).

How blank my face is. Until you see yourself, you do not know what you look like. I am not even smiling, I do not smile (Amber). 


\begin{tabular}{|c|c|c|c|c|c|c|c|c|}
\hline \multirow{2}{*}{ 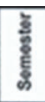 } & \multirow{2}{*}{ Dates } & \multirow{2}{*}{$\frac{x}{3}$} & \multicolumn{4}{|c|}{ Master of Teaching \& Learning } & \multirow{2}{*}{$\frac{2}{6}$} & \multirow{2}{*}{ SCHOOLS } \\
\hline & & & \multirow[t]{2}{*}{2016 Year Plan } & \multicolumn{3}{|c|}{ Papers } & & \\
\hline \multirow{8}{*}{ 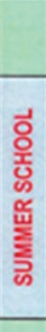 } & 28 Dec - 1 Jan * & 0 & & \multirow{10}{*}{ 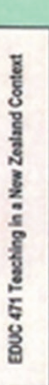 } & & & 0 & \\
\hline & $4-8 \operatorname{Jan} *$ & 1 & Programme begins Tue 5 Jan & & \multirow{15}{*}{ 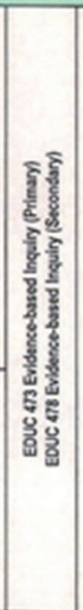 } & \multirow{15}{*}{ 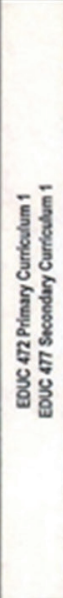 } & 1 & \\
\hline & 11-15 Jan & 2 & & & & & 2 & School Holidays \\
\hline & $18-22 \mathrm{Jan}$ & 3 & & & & & 3 & \\
\hline & 25-29 Jan & 4 & $\bullet$ & & & & 4 & \\
\hline & $1.5 \mathrm{Feb}$ & 5 & \multirow{2}{*}{2 weeks in Schools } & & & & 5 & \multirow{11}{*}{$\begin{array}{l}\text { TERM } 1 \\
\text { (11 wooks) } \\
\text { schools start botween } \\
\text { lon } 1 \text { and Fri } 5 \text { Feb \& } \\
\text { finish Fri } 15 \text { Aor }\end{array}$} \\
\hline & 8-12 Fob• & 6 & & & & & 6 & \\
\hline & 15.19 Feb & 7 & $\bullet$ & & & & 7 & \\
\hline & $22-26 \mathrm{~F} o b$ * & 8 & $\bullet$ & & & & 8 & \\
\hline \multirow{19}{*}{ 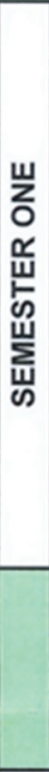 } & $29 \mathrm{Fob}-4 \mathrm{Mar}$ & 9 & $\bullet$ & & & & 9 & \\
\hline & 7-11 Mar & 10 & $\bullet$ & \multirow{6}{*}{ 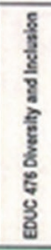 } & & & 10 & \\
\hline & 14-18 Mar & 11 & $\bullet$ & & & & 11 & \\
\hline & 21-25 Mar* & 12 & $\diamond$ & & & & 12 & \\
\hline & 28 Mar- 1 Apre & 13 & $\diamond$ & & & & 13 & \\
\hline & 4-8 Apr & 14 & $\diamond$ & & & & 14 & \\
\hline & 11-15 Apr & 15 & $\bullet$ & & & & 15 & \\
\hline & $18-22 \mathrm{Apr}$ & 16 & \multirow{2}{*}{\multicolumn{4}{|c|}{ MID-SEMESTER BREAK }} & 16 & \multirow{2}{*}{ School Holidays } \\
\hline & -25-29 Apr • & 17 & & & & & 17 & \\
\hline & 2-6 May & 18 & $\bullet$ & & हरํํำ & & 18 & TEPM? \\
\hline & 9-13 May & 19 & $\diamond$ & 을 & हᄐ & $\bar{E} \bar{g}$ & 19 & (10 wooks) \\
\hline & 16-20 May & 20 & & 를 & 这 & 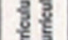 & 20 & Allechomes $\mathrm{C}$ \\
\hline & 23-27 May & 21 & Professional Experience & $\frac{2}{2}$ & $\frac{8}{8} \frac{8}{8}$ & 这 & 21 & 2 May to 8 July \\
\hline & 30 May - 3 Jun & 22 & (full-time in schools) & है & 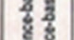 & $\frac{1}{2} 8$ & 22 & \\
\hline & *6-10 Jun & 23 & & $\xi$ & 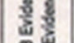 & 怘 & 23 & \\
\hline & 13-17 Jun & 24 & $\diamond$ & ב्. & 5 & ప్ & 24 & \\
\hline & 20-24 Jun & 25 & $\diamond$ & & 룸욤 & & 25 & \\
\hline & 27 Jun - 1 Jul & 26 & BREAK & & & & 26 & \\
\hline & 4-8 Jul & 27 & Denem & & & & 27 & \\
\hline & 11-15 Jul & 28 & & & & & 28 & carnoturin \\
\hline & 18-22 Jul & 29 & & & ริโูญ & & 29 & School Holidays \\
\hline & $25-29 \mathrm{Jul}$ & 30 & $\diamond$ & & 을 & $\simeq \approx$ & 30 & \\
\hline & 1.5 Aug & 31 & $\bullet$ & 题 & 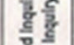 & हE & 31 & (9 weeks) \\
\hline 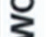 & 8-12 Aug & 32 & $\bullet$ & $\frac{5}{8}$ & 赔 & 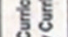 & 32 & All schor \\
\hline$F$ & 15-19 Aug & 33 & & हत हू & 8 & ํํㄹㄹ & 33 & 25 July to 23 Soptember \\
\hline 嵒 & 22-26 Aug & 34 & & 容 & 兑总 & 范多 & 34 & \\
\hline 占 & 29 Aug - 2 Sep & 35 & Professional Experience & 8 & हुํํำ & प्र & 35 & \\
\hline Ш & 5-9 Sop & 36 & (full-time in schools) & & 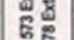 & & 36 & \\
\hline Ш & 12-16 Sep & 37 & & & 墒客 & & 37 & \\
\hline & 19-23 Sep & 38 & & & & & 38 & \\
\hline & 26-30 Sep & 39 & BREAK & & & & 39 & \\
\hline & 3-7 Oct & 40 & BREAK & & & & 40 & School Holidays \\
\hline & $10-14 \mathrm{Oct}$ & 41 & $\diamond$ & & हह & & 41 & \\
\hline & 17-21 Oct & 42 & $\diamond$ & & 8 & & 42 & TERM 4 \\
\hline & -24-28 Oct & 43 & $\bullet$ & $\frac{8}{3}$ & $\frac{2}{2}$ & $\tilde{\tilde{c}} \tilde{\xi}$ & 43 & (10 weeks) \\
\hline & 31 Oct - 4 Nov & 44 & $\diamond$ & $\frac{2}{2}$ & $\frac{1}{8}$ & 呢展 & 44 & All Schools start \\
\hline & $7-11 \mathrm{Nov}$ & 45 & $\diamond$ & $\frac{8}{2}$ & 然 & 8 & 45 & \\
\hline & $14-18$ Nov & 46 & $\diamond$ & $\frac{\mathrm{z}}{\partial}$ & 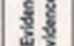 & है & 46 & $\begin{array}{l}\text { Primary \& Intermediato } \\
\text { Schools finish no later than }\end{array}$ \\
\hline & 21-25 Nov & 47 & $\diamond$ & 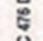 & 묭 & ${ }_{0}^{\infty}$ & 47 & Tue $20 \mathrm{Dec}$ \\
\hline & 28 Nov $-2 \mathrm{Dec}$ & 48 & $\diamond$ & g & 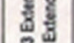 & वे. & 48 & Secondary \& Composite \\
\hline & 5-9 Doc & 49 & $\diamond$ & & $\begin{array}{ll}50 \\
38\end{array}$ & & 49 & $\begin{array}{l}\text { Schools finish no later than } \\
\text { Fri } 16 \text { Doc }\end{array}$ \\
\hline & 12-16 Dec & 50 & \$ Programme ends Fri 16 Doc & & 递 & & 50 & \\
\hline & 19-23 Dec & 51 & CHRISTMAS/NEWY & & & & 51 & School Holidays \\
\hline
\end{tabular}

Figure 1: Master of teaching and learning 2016 year plan 


\begin{tabular}{|c|c|c|}
\hline Milestone & Date & Activity \\
\hline 1 & By January $29^{\text {th }}$ & $\begin{array}{l}\text { Student teachers completed Video Capture 1: } \\
\text { Practiced videoing on their own personal device } \\
\text { Uploading a video to the annotation platform/software } \\
\text { Using the video capture system to annotate a segment of video to include both graphic and textual annotations } \\
\text { Initiate a narrative thread with their self-selected community of practice } \\
\text { Participate in narrative threads initiated by members from their community of practice } \\
\text { Export their initiated narrative thread }\end{array}$ \\
\hline \multicolumn{3}{|c|}{$\begin{array}{l}\text { The MTchgLn program assigned student teachers to a partner school from the beginning of Term } 1 \text { (Figure 1). Student teachers were in their partner school } \\
\text { for a 2-week observation block }\end{array}$} \\
\hline 2 & By February $12^{\text {th }}$ & Student teachers obtained ethics for the use of video capturing in their partner school class \\
\hline 3 & By April $1^{\text {st }}$ & $\begin{array}{l}\text { Student teachers selected a curriculum event from professional experience that provoked their thinking or practice in } \\
\text { some way (this did not have to be a negative event). Student teachers wrote up this event as a narrative. This event was } \\
\text { used to complete video capture } 2\end{array}$ \\
\hline 4 & By April $8^{\text {th }}$ & $\begin{array}{l}\text { Student teachers explained why the event was significant using the video capture to highlight (graphics) and annotate } \\
\text { (text on video) the video footage to include personal and theoretical perspectives and understandings in comments } \\
\text { section. Students were then to initiate a narrative thread with their community of practice to deconstruct what happened } \\
\text { noting dominant constructions of curriculum and how their students' experienced curriculum }\end{array}$ \\
\hline 5 & By April $15^{\text {th }}$ & $\begin{array}{l}\text { Student teachers re-theorized what they had learned from video capture } 2 \text { as it pertained to their teaching practice and } \\
\text { how they were adapting their teaching practice for future teaching within the partner school context }\end{array}$ \\
\hline 6 & By June $24^{\text {th }}$ & $\begin{array}{l}\text { Student teachers complete } 4 \text {-week block course and select a curriculum event from professional experience that } \\
\text { provoked their thinking or practice in some way and initiate narrative thread with their community or practice }\end{array}$ \\
\hline 7 & By September $23^{\text {rd }}$ & $\begin{array}{l}\text { Student teachers complete } 6 \text {-week block course and select a curriculum event from professional experience that } \\
\text { provoked their thinking or practice in some way and initiate narrative thread with their community or practice }\end{array}$ \\
\hline 8 & By December $2^{\text {nd }}$ & Student teachers discuss the benefits and limitations of using video capture in ITE \\
\hline
\end{tabular}

ITE: Initial teacher education, MTchgLn: Master of teaching and learning

When I watched myself, I just saw that I was very unsure of myself. I would say something and then go back on it and the children were just confused (Laura).

Before the March focus group, the student teachers had been in their partner school for an orientation 2-week block placement and 3 weeks of 2-day/week (Figure 1). At this point, in the program, these student teachers were focused on the "negatives" when they viewed their videos. The authors questioned these student teachers why they had focused only on the negative aspects. The following quote from Chris was representative of what the students' responded, "I think it's just natural in self-reflection to focus in on the negative. It is easier to look at improving what is not going right". Although the student teachers focused on what they perceived as "negative" aspects of their teaching, they all noted the fact that they were using these negative reflections for how they could improve.

Further exploration of how these students were using video captures of teaching practice revealed how these student teachers were noticing the similarities and differences in teaching practice. When prompted for specifics of teaching practice of their colleagues, these student teachers highlighted:

Good to see a range of practices. Amber and I were both doing guided reading. Interesting to see the differences in how we taught the groups (Chris).

Different ways they [Laura, Chris and Amber] manage the class and giving instructions (Lucy).
Looking at how long Laura has her children on the mat compared to how long I have mine on the mat for. The questioning we are using, the prompting that Laura is using that I am not because my children are older (Amber).

At this point, in their ITE program, these student teachers were questioned about what they saw as beneficial from video capturing. Chris commented that "it forces you to be selfreflective... Being involved in this program, being reflective is the key focus of the year and the videoing is a great opportunity to make sure you are". A discussion ensued about what they meant and how the use of the video capturing assisted them to be critically reflexive. Lucy stated, "for me being reflective is basically knowing when you look back that something might not be working in what you are doing and it's okay to realize that it is not going so well. The reflexive part is thinking about what I can do to fix it".

The MTchgLn program, through the use of video capturing, explicitly sought to scaffold these student teachers from reflection about their teaching practice to critical reflexivity. All four student teachers made comments demonstrating that they had engaged in reflection on action when they viewed their videos. "Realizing that not everything you do has to be set in stone and that it is okay to make changes" (Lucy). Amber described a typical example of these student teachers' reflection in action. She reported that she was able to make an on-the-spot observation about how the children were responding to her instructions and thought, "I need to stop right now and change what we are doing". More importantly for this study, Chris believed that video capture was supporting his developing 
reflection for-action. Through the video capturing and community of practice discussions, not only was he identifying what was the catalyst for what was not only working but also what he could now do differently in his teaching. All of these student teachers commented that they could see reasons in their videos of teaching practice for why and how they need to be adaptable and flexible in their teaching.

After 3 months in this program, the combination of theory and practice and video capturing of their teaching practice was having a positive effect on these student teachers. Then, the program's consistent intensive structure and requirements began to impact on these student teachers. By the end of Term 1 (Figure 1), the student teachers were required to have taken responsibility for one reading and one mathematics group and whole class daily routines. Then, in Term 2, they increased this responsibility to half the reading and mathematics groups leading into their four-week sustained teaching block. This progression and scaffolding of student teachers' classroom practice, was designed to allow them to develop their confidence and skills as they increasingly take on more of the role of the teacher.

\section{Identified Benefits of Using Video Capture and Peer Feedback}

The April focus group occurred during the school term break, Figure 1. The student teachers identified three benefits of using video capture and receiving peer feedback on their teaching. These benefits included: Developing confidence and their "teaching persona" to act and feel like a teacher (FeimanNemser, 2008); reflecting on what went well rather than just what needed to be improved to develop their knowing as a teacher (Feiman-Nemser, 2008); and, giving and receiving constructive peer feedback on teaching practice as they develop how to think like a teacher (Feiman-Nemser, 2008).

\section{Developing Confidence and a "Teaching Persona"}

During this focus group interview, however, the students stated that they were now expected to teach more and that it was easier to video themselves and then review it together. Amber's comment was indicative of the group, "It is hard to try and find the time to pair up, which is what we initially thought we would do. Now that we are further down the track with our teaching, it is easier to film ourselves". The student teachers commented on their facial expressions and mannerisms as well as their "teaching persona" when they discussed the benefits of using video capture to reflect on their teaching. The student teachers noted that it made them more aware of how they could be perceived by the children when they were teaching. Lucy stated that while she did not like to hear herself on the video, she could identify that the children did not understand what she expected them to do due to how she delivered the instructions:

As much as I hate it, hearing myself and thinking that's how I actually said it. I introduced a new game in maths, and I created these resources. I thought I had made [the instructions] really clear. When I went back over the video, I can understand why I got four questions about it because I was not clear.
Amber commented that she noticed her lack of facial expression when she spoke to the children. "I noticed I don't smile... Watching [the video] and thinking I am so serious. But you are actually enjoying being there. They are probably thinking that Amber is an old witch... You do pick up little things. Just the way you explain and do things".

Chris stated that the video allowed him to reflect on the tone of voice he used when he spoke to the children. "You cannot pick up tone by sitting down and reflecting about it. You need to hear it".

\section{Reflecting on What Went Well Rather than Just What Needed to be Improved}

As the student teachers became more comfortable and confident seeing themselves on video, they focused more on what they were doing when they were teaching. Lucy's quote is representative of the comments, "I just think [videoing] is really helpful. I look at the video and I see so much more than I had previously... I considered what went well and what didn't go so well and reflect on ways to improve it".

When the student teachers became more comfortable and confident with how they looked and acted as a teacher, the focus centered more on thinking and knowing like a teacher. They reported using a more critical lens to view the videos. Not only did they reflect on the aspects of their classroom practices that were going well and why but also on those aspects that could be improved and what strategies they could employ.

\section{Giving and Receiving Constructive Feedback on Teaching Practice to Develop Thinking Like a Teacher}

The student teachers stated that having another person review the video with them was beneficial. They commented on how the other person noticed different aspects of their teaching from what they had reflected on when watching the video. Amber appreciated "listening to other people's opinions rather than just your own thoughts on how a lesson went. Things that you do not even pick up on". Laura echoed Amber and reflected on how she could adapt her teaching and for different contexts. "Sitting down and discussing [the video of the teaching] with people. They are noticing more. In addition, it is a chance to look at it again from a different perspective and then being able to adapt it ... trying it a different way or in a different context and seeing if that works".

\section{Program Design Impacts}

Due to the intensive demands of program, the student teachers did not continue weekly videoing and reviewing of their teaching in Term 2. As the video capturing component of the program was not assessed, and they received oral and written feedback from their Mentor Teacher, the videoing was not viewed as having the same importance as previously assigned by the students. They noted how their planning and teaching along with the increasing workload necessary as they assumed more of the day-to-day life of a teacher made this extra voluntary work less of a priority. 
These student teachers were assigned to four different schools for the second semester of the program, Figure 1. Two of these participants, Laura and Lucy, continued to use the video capturing system on an occasional basis while the other two chose not to continue using the technology. At the participating student teachers' request, focus group sessions were not held until after the 6-week block placement was completed and these student teachers were nearing the end of their program. The final focus groups were held in late November.

\section{Student Teachers' Learning to Think, Know, Feel, and Act Like a Teacher}

One of the purposes of ITE is to challenge student teachers' preconceptions of teaching and being the teacher (Haigh, 2013; Simpson and Grudnoff, 2013). Initial findings from Semester 1 indicated that this MTchgLn program was having a positive impact on these four student teachers. The responses of the student teachers about their experiences of using video capture to reflect on their teaching demonstrated the gaps Thompson and Pascal (2012) identified as missing from Schön's (1987) reflective practice: Reflection for-action and the significance of language, meaning and narrative. Through video capturing and its associated narrative threads, these student teachers were able to note not only their assumptions, belief, values, and preconceptions but also how their students were experiencing the learning. Through their critical reflexive narratives, these student teachers were beginning to think, know, feel, and act like a teacher.

In the November focus group, the student teachers discussed how they saw video capturing impacting on their self-asteacher role identity. Both Laura and Lucy who continued to use the technology were more effusive on its benefits than Amber and Chris. Both Lucy and Laura saw videoing of teaching practice as a transformative tool for their teacher development. When asked for specifics they noted:

My tone with the children ... my mannerisms (Lucy).

How far my confidence has grown ... I can see I have a new teaching style that is more me (Laura).

Lucy noted that it was going back over her videos in preparation for the final assessment in which she is presenting her learning journey over the course of this year that she has noticed how transformative her teaching practice has been from the start to finish. She stated:

Just looking at it, you can actually see the transformation, but it is just being able to go over it, re-visit it, and actually be able to see how you are and how you have improved and what you have changed in your teaching.

For Laura the transformation was most visible in her confidence at being the teacher. In reviewing her videos from Semester 1, she highlighted how she could see that she was just going with the flow of what her mentor teacher was doing. She was not willing to try anything or be anything other than a version of her mentor teacher. Now she can see her teaching as more reflective of whom she is and how she wants to teach. She could see in her Semester 2 videos how she was thinking and feeling about her teaching. More importantly, she was able to use her videos as a tool of critically reflexivity to examine how she taught, what she taught, how she valued the content and how her students perceived her delivery.

This MTchgLn program and its student teachers created an environment where the student teachers felt comfortable enough to critically question and examine their own teaching practice openly. Lucy and Laura took advantage of the opportunities to engage in critical reflexive dialogue with both themselves through their reflexive journals, course assessments and with each other. These student teachers' experiences in reconciling their expectations with actual experiences support the research that authentic experiences are critical to developing teacher efficacy (Korthagen et al., 2008). Realistic teacher education is evidence-based practice, but this evidence is based in the student teachers' own teaching practice.

Both Chris and Amber noted that the shifting to a new school and new environment made the use of this video capturing too problematic. They both have their own devices that they used to gather evidence to assessments but as this study's video capturing was not required, it got pushed to the side to complete assessments and placement requirements. Both agreed with Lucy and Laura that it needed to be mandatory as Chris noted now that looking back over the semester 1 videos, he wished he had done more.

When prompted to explain why, Chris noted that like most of his colleagues he started reviewing his teaching videos by looking at only the negatives in his teaching practice. After the first focus group, he had to learn to look for how he was working toward his two main teaching goals. He wanted to be a more effective teacher so he needed to focus on how he was going to be more effective rather than what he was doing wrong. His videos of teaching practice noted he only focused on surface questions so he needed to incorporate his teaching goal of asking more meaningful questions. The videos of teaching practice in semester 1 showed him how he was working to implementing Bloom's Taxonomy. Second, he started this year with differentiated planning for outliers in the classroom. It was through critical reflections of his teaching videos that highlighted how all his students are individuals. This required him to modify his second goal of planning for individuals in the classroom. Once he shifted schools, these goals remained, and he wished he had videoed himself to see how he actually continued to use meaningful questioning and differentiated learning in his teaching. His final comments on videoing highlight the significance of this technology for ITE, "I didn't think I would grow as much as I did, I just wish I had the videos to show it."

\section{FINAL THOUGHTS}

This study's MTchgLn program was designed to support these student teachers in using their own classroom experiences 
in a critically reflexive process to facilitate gestalts (Lind, 2013; Ministry of Education, 2016). It was anticipated that these student teachers' initial sense of self-efficacy would be challenged by the realities of classroom experience. It was also anticipated that through communities of practice, their video capturing would provide the opportunities necessary for these student teachers to explore their own beliefs about teaching and being the teacher.

Realistic teacher education builds on student teachers' own experiences, perceptions, thinking, feelings, and concerns in which they were actively involved (Korthagen et al., 2008). This was evident in the video capture group sessions. These sessions provided these student teachers with an opportunity to discuss how their classroom experiences were affecting their sense of self-efficacy. These sessions also provided these student teachers with the support and guidance necessary to use their experiences as an opportunity for growth and learning in their teaching practice based on their professional experiences (Cunliffe, 2004; Thompson and Pascal, 2012; Timperley, 2013). Both student teachers who were self-directed enough to continue using the video capturing technology were able to see the benefits as they looked back over their progression. The two student teachers who were unable to continue videoing in Semester 2 both realized how they could have benefitted if this had been a mandatory course component.

This study concerned only four student teachers involved in an exemplary MTchgLn program and cannot be considered as indicative for all MTchgLn students or ITE programs. These student teachers have provided enough evidence for this MTchgLn program to re-examine how videoing of student teacher practice should be incorporated. The student teachers' suggestion that videos of teaching practice taken at the beginning and end of each block would probably allow students to see their own development and progression. This ITE program will continue to use video capture so student teachers have the artefacts necessary for critical reflection of their teaching practice. It is hoped for and anticipated that, like Lucy and Laura, student teachers will want to continue with this in their own teaching.

\section{REFERENCES}

Ballard, K. (2012). Inclusion and social justice: Teachers as agents of change. In: Carrington, S., \& Macarthur, J., (Eds.), Teaching in Inclusive School Communities. Milton, Australia: John Wiley \& Son's Australia. pp. 65-87.

Charteris, J., \& Smardon, D. (2013). Second look-second think: A fresh look at video to support dialogic feedback in peer coaching. Professional Development in Education, 39(2), 168-185.

Conner, L., McGrath, A., \& Lancaster, N. (2008). Where to now for teacher education? Stakeholder view of the aims of education and initial teacher education programmes in New Zealand. Pacific-Asian Education, 20(1), 19-32.

Cunliffe, A.L. (2004). On becoming a critically reflexive practitioner. Journal of Management Education, 28(4), 407-426.

Feiman-Nemser, S. (2008). Learning to teach. In: Goodman, R., Flexner, P., \& Bloomberg, L., (Eds.), What We Now Know about Jewish Education: Perspectives on Research for Practice. Los Angeles, CA: Torah Aura. pp. 213-222.
Feldman, A., Chapman, A., Vernaza-Hernández, O.D., \& Alshehri, F. (2012) Inquiry-based science education as multiple outcome interdisciplinary research and learning (MOIRL). Science Education International, 23(4), 328-337.

Groundwater-Smith, S., Ewing, R., \& Le Cornu, R. (2006). Teaching: Challenges and Dilemmas. Melbourne, VIC, Australia: University Press.

Haigh, M. (2013). Are they ready to teach? Judging student teachers' practice. Set: Research Information for Teachers, 3, 3-10.

Hatch, T., \& Grossman, P. (2009). Learning to look beyond the boundaries of representation: Using technology to examine teaching (overview for a digital exhibition: Learning from the practice of teaching). Journal of Teacher Education, 60(1), 70-85.

Hattie, J.A.C. (2009). Visible Learning: A Synthesis of Over 800 MetaAnalysis Relating to Achievement. Abingdon, Oxon, England: Routledge.

Hoban, G.F., (Ed.) (2005). Developing a multi-linked conceptual framework for teacher education design. In: The Missing Links in Teacher Education Design: Developing a Multilinked Conceptual Framework. Dordrecht, Netherlands: Springer. p. 1-17.

Kane, R.G. (2005). Initial Teacher Education Policy and Practice-Final Report. Available from: https://www.educationcouncil.org.nz/sites/ default/files/itepolicyandpractice.pdf. [Last accessed on 2017 Jun 19].

Korthagen, F.A.J., Kessels, J., Koster, B., Lagerwerf, B., \& Wubbels, T. (2008). Linking Practice and Theory: The Pedagogy of Realistic Teacher Education. New York, NY: Routledge.

Lave, J., \& Wenger, E. (1991). Situated Learning: Legitimate Peripheral Participation. Cambridge, England: Cambridge University Press.

Le Cornu, R. (2010). Changing roles, relationships and responsibilities in changing times. Asia-Pacific Journal of Teacher Education, 38(3), 195-206.

Lind, P. (2013). What are the characteristics of exemplary initial teacher education programmes in countries similar to Aotearoa/New Zealand? Waikato Journal of Education, 18(1), 87-99.

Ministry of Education. (2007). The New Zealand Curriculum. Wellington, New Zealand: Learning Media.

Ministry of Education. (2016). Lifting the Quality of Initial Teacher Education Provision (ITE). Available from: http://www.education. govt.nz/ministry-of-education/specific-initiatives/lifting-the-quality-ofinitial-teacher-education-provision. [Last accessed on 2017 Jun 19].

Nokes, J.D., Bullough, R.V., Egan, W.M., Birrell, J.R., \& Hansen, J.M. (2008). The paired placement of student teachers: An alternative to traditional placements in secondary schools. Teaching and Teacher Education, 24, 2168-2177.

Parata, H. (2014). Announcement of Further ITE Provision. Available from: http://www.beehive.govt.nz/release/announcement-further-iteprovision. [Last accessed on 2017 Jun 19].

Schön, D. (1987). Educating the Reflective Practitioner. San Francisco, CA: Jossey-Bass

Seraphin, K.D., Philippoff, J., Kaupp, L. \& Valiin, L.M. (2012). Metacognition as means to increase the effectiveness of inquiry-based science education. Science Education International, 23(4), 366-382.

Simpson, M., \& Grudnoff, L. (2013). From preparation to practice: Tensions and connections. Waikato Journal of Education, 18(1), 71-82.

Steed, C., \& Poskitt, J. (2010). Adaptive help seeking: A strategy of self-regulated learners and an opportunity for interactive formative assessment. Assessment Matters, 2, 86-106.

Thompson, N., \& Pascal, J. (2012). Developing critically reflective practice. Reflective Practice, 13(2), 311-325.

Timperley, H. (2013). Learning to Practice: A Paper for Discussion. Wellington, New Zealand: Ministry of Education.

Timperley, H., Wilson, A., Barrar, H., \& Fung, I. (2007). Teacher Professional Learning and Development: Best Evidence Synthesis Iteration. Wellington, New Zealand: Ministry of Education.

Youens, B., Smethem, L., \& Sullivan, S. (2014). Promoting collaborative practice and reciprocity in initial teacher education: Realising a 'dialogic space' through video capture analysis. Journal of Education for Teaching: International Research and Pedagogy, 40(2), 101-113. 